\title{
TWO NEW TABLETS THROWING LIGHT ON THE RELATIONS BETWEEN ANATOLIAN KINGS AND ASSYRIAN MERCHANTS IN THE PERIOD OF THE ASSYRIAN COLONIES*
}

We do not have detailed knowledge of the formal or informal relations of the Assyrian merchants with the kings or outstanding natives in Anatolia, because an important part of the tablets found at Kültepe deals mostly with the private affairs of these merchants. The scanty material related to the subject has been scattered over various tablets in accordance with the merchants' interest, and in most cases it is worded so shortly and with so unintelligible phrases that it is almost impossible to get a clear idea what the situation referred to is. This lack of material related to the subject can be explained to some extent by the fact that the Anatolian kings in matters of public importance preferred to deal not with the individual persons, but directly with certain public institutions, the functions of which are still not completely understood, and possibly with the delegations made up of the rich and important merchants. In other words the cause of this lack of information seems to have been mainly to office of kärum (büt kärim) and some representative institutions. On the other hand we find some kings correspond with individual merchants and act as if they are businessman. The following letter offers a new and good example of this kind.

No.1

Excavation Inv. no. Kt. $85 / \mathrm{k} 27$

This latter is addressed by the rubä'um (king) of Tuhpia to a merchant called Itür-ilit.

The king in retum for two pieces of cloth, one kutänum and the other kusitum, which he had received from Itür-ili, has entrusted to Amunani 80

* This article was presented in Turkish to the XIIth Turkish Congress of History, Ankara 1994, but the report on articles has not yet published until now. 
minas of good quality copper to give to Itür-ili (L. 3-7). He also seems to have paid to both Ennum-Ašsur and Sü-Laban 50 minas of good quality copper each for the pieces of kutânum- cloth which he received as erbum (L. 8-15). The king again in return for the erbum he has received from It $\bar{u} r-i l \bar{l}$ entrusts to Amunani also two skins of wine of which he speaks as "my erbum" (L. 16-20).

Starting from the line 21 , there seems to be a disagreement between the king and the person called Išme-Ašsur, perhaps a representative of Itur-ill, about the amount to be paid fui the erbum. As understood from the letter lisme-Ašsur brings to the king a ccrtain amount of amütum and at the same time a piece of kutânum-cluth as erbum. The king gives him $100<$ minas $>$ of Tuhpia-copper in return for the erbum. But Isme-Ašsur possibly judging the amount of copper he has been offered less than what he thinks he deserves, refuses to accept it. Then the rubä' um leaves the amount of copper he has offered in trust at the house of a person called Zumea and after somctime by giving to Su-Bélum who has come to Tuhpia, an additional amount of 50 minas of Tuhpia-copper, 30 minas of good quality copper and two jars of oil, to be handed over to Isme-Ašsur the king tries to satisfy him.

Obv.1. um-ma ru-b[a-um]-ma șa Tủ-ùh -pì-a-ma

a-na I- $\left\ulcorner\operatorname{tur}_{4}\right\urcorner$-DINGIR qi-bi-ma

1 TƯG ku-ta-nam <ù> 1 TÚG ku-sí-tám

tù-šé $<b i_{4}>-\mathrm{lam} /$ ší-im-šu-nu

5. a-dí-ni / láa-dí-na-kum

80 má-na URUDU SIG $_{5}$ ší-im

TÚG A-mu-na-ni na-áś-a-kum

1 TÚG ku-ta-nam En-um-A-šur

a-na er-bi ${ }_{4}$-im i-šía-am

10. 1 TÚG ku-ta-nam Šu-Lá-ba-an

a-na er-bi ${ }_{4}$-im i-ší-a-am

50 ma-na URUDU SIG $_{5}$ a-na

En-um-A-ŝ́ur a-dí-in

50 ma-na URUDU SIG $_{5}$ a-na 
15. Šu-Lá-ba-an a-dí-in

Edge a-ta er-ba-am tù-šé-bi ${ }_{4}$-lam

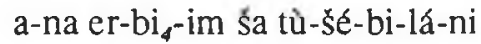

Rev. 2 zi-qú-qá!-tim ša DUG!

ki-ra-na-am er-bi ${ }_{4}$

20. A-mu-na-ni na-âš-a-kum

Iš-ma-A-śur a-mu-tám ub-lam-ma

1 TÚG ku-ta-nam er-ba-am

i-ší-a-am / a-na cr-bi ${ }_{4}-$ șu $^{\prime}$

1 me-at <ma-na> URUDU ša Tù-ùh-pì-a

25. a-dí-šu-um-ma / lá-qá-am

lá i-mu-a-ma / É Zu-me-a

e-zi-ib-šu-ma / Šu-Be-lúm i-li-kam-ma

50 ma-na URUDU sa Tù-ùh-pì-a

30 ma-na URUDU SIG <ù> $_{2}$ kà-ar-pá-tim

30. Ša śa-am-ni-im a-dí-śu-um

ša er-bi ${ }_{4}$-im ša Iś-ma-A-šur

lu er!-ba-am lu ša ha-bu-lá-ku-ni

ša-bu-a-tí / mì-ma

i-na É.GAL Lim lá tí-šu

Translation:

(1-2) "Thus (says) the rubā' um of Tuhpia: "Speak to Itür-ilī: (3-5) You sent me a piece of kutānum-cloth (and) kusitum-cloth, (but) I have not paid you their cost by now. $(6,7)$ Amunani is bringning to you 80 minas of good quality copper in payment for the cloth. (8-9) Ennum-Ašsur had brought me as erbum a piece of kutānum-cloth. (10-11) $\tilde{S} u$-Lâban had brought me as erbum a piece of kutānum-cloth. (12-13) I gave 50 minas of good quality copper to Ennum-Aššur. (14-15) I gave 50 minas of good quality copper to Sü-Läban. (16) You sent me an erbum. 
(17-20) In retum for the erbum you sent me Amunani is bringing to you two skins! of wine (as) my erbum'(s cost). (21-23) I'sme-A Ašsur brought me the amütum and (also) brought a piece of kutänum-cloth to me as erbum. (23-27) In return for his erbum I gave him $100<$ minas $>$ of Tuhpia copper but he refused to accept it and so I left it (copper) in Zumea's house. (27-31) Sü-Bēlum came here and in retum for Išme-Aššsur's erbum I gave him 50 minas of Tuhpia copper, 30 minas of good quality copper (and) 2 jars of oil. (32-33) Both the price of erbum and my debt to you (for all other things) have been paid completely. (33-34) The palace owes you nothing (you have nothing to claim in the palace)".

\section{Notes:}

L.1: Tuhpia, known to us a center of wabartum and famous for it's copper mines (K. Nashef, RGTC IV, p.122-123), is localized with general acceptance somewhere in between Boğazköy and Merzifon:

Tuhpia in a letter of the karum Kanis (Kt. 92/k 203, 4-6), which has not been published yet, is listed together with karums Turhumit, Hattus and Tamnia. Probably Tuhpia was a center of both wabartum and kârum.

L.2: We de not have detailed information about commercial activities of $l t \bar{u} r-i l \bar{l}$ the addressee in the rubä'um's letter. But as understood from the letter, he is a reputable merchant who has close relations with the king.

In a tablet containing judicial record which has not been published yet (Kt. j/K 80) there seems to be dispute between Hanu the son of Itür-ili and the person called $\tilde{S} u-L a \bar{b} b a n$. In the course of the case Hanu speaks to $\tilde{S} u$-Lāban thus:

(4)....... 40 TÚG ku-ta-nu (5) ša qá-tim 2 TÚG a-bar-ni-e ša a-bi $i_{4}-n i$ (6) a-na ru-ba-im Tù-üh-pi-a-i-im (7) a-dí-na-kum

"I gave you 40 (pieces of) kutānum-cloth of the normal quality (and) 2 (pieces of) abarnium-cloth which belonged to our father to deliver the Tuhpian rubă' um." Itur-ilit.

It is easy to understand the pieces of cloth mentioned here belong to

Also the letter written by Išme-Aššur to Itür-ilī (TC I, 39) seems to be closely related to our subject under discussion. It reads thus:

1. L.L. Orlin, ACC, p.38, 86; M.T. Larsen, OACC, p.240; cf. M. Forlanini, Hethitica VI, p.67 (map). 
(4) a-na Tuh-pi-a e-ru-ub-ma (5) ur-kd-at'su / a-ma-lá (6) tu-ša-hi-zi-ni (7) ra-qà-tám ù lu-bu- $̧ a-a m(8)$ a-na ru-ba-im / a-ši-ma (9) ù a-ha-ma 10 TUG.HI.A (10) ù a-š-a-am ú-šé-li-ma (11) a-ší-am ù TUG.HI.A (12) ú-ta-e-ra-am-ma (13) er-ba-am im-ta-ha-ar (14) um-ma su-ut-m[a] úlá (15) a-lá-qé a-na er-bi,-im (16) ša a-ši-ú-su-ni (17) [x GÚ x] ma-na URUDU (18) [ša Tun-pí]-a ú-śé-ri-du-nim

(4-8) "I came to Tuhpia and afterwards in accordance with your instructions I took the raqqatum-cloth and the dress to the king. (9-10) I also took 10 pieces of cloth and aši' um-metal to him. (11-13) He gave me back the as i' um-metal and the pieces of cloth, but accepted the erbum. (14-15) He said thus: "I will not take (any of those goods you brought except for the one 1 ordered)'. (15-18) In return for the erbum I took to him they sent me [x talent $\mathrm{x}$ ] minas of [Tuhpi]a copper."

It is quite obvious that Išme-Ašsur the writer of this letter (TC 1, 39) is the same person referred to in the 21 . and 31 . lines of $\mathrm{Kt} .85 / \mathrm{k} 27$. So we can say that ISme-Ašsur is a trustworthy representative of $/ i \bar{u} r$-ili and he often brings from Itür-ili to the rubä'um of Tuhpia goods such as cloth, clothing and precious metals.

L. $3 \mathrm{ff}$ : It is understood that two different kinds of cloth one kutānum the other kusitum has been brought to the rubä'um and it is said that for two pieces of cloth one bcing kutānum and the other kusitum a total of 80 minas of good quality copper have been paid, for each piece of kutânum-cloth a sum of 50 minas of good quality copper ${ }^{2}$. So we understand that for a piece of kusitum-cloth a sum of 30 minas of good quality copper has been paid.

L. $6 \mathrm{ff}$ : We understand that there was a quite a big difference of quality berween URUDU SIG $_{5}$ "good quality copper" and URUDU $\bar{s} a$ Tuhpia "Tuhpia copper" as we mentioned above, although 50 minas of good quality copper has been paid for each piece of kutanum-cloth (L.8-15), the price that is asked for another kind of kutänum-cloth is 100 minas of Tuhpia copper (L.22-25). 224,8 .

L.7, 20: Amunani, the person mentioned here also occurs in Kt. a/k

L.9: The word erbum is used nine times in the tablet. CAD gives

2. We find in the texts different prices paid for the kutanum-cloth depending on the quality of it. See K.R. Veenhof, AOATT, p. $82 \mathrm{ff}$.

3. We read in one of the unpublished tablets (Kt n/K 520, 14-16) the sentence URUDU SIG $\mathrm{K}_{5} \mathrm{Kaki}$ ana Tuhpia ublakkum "Kaki has brought to Tuhpia to you good quality copper". 
under irbu one of its meanings in Old Assyrian language as "import duty". K.R. Veenhof suggests that it is "gift" (T. Ozgüç Festschrift. p.523); whereas K. Balkan claims that erbum is a gift brought to rubä' um or rubätum and it has nothing to do with any kind of trade duty (Kronoloji, p.37).

It is quite clear that erbum in the context in which it has been used here in this tablet has a different meaning than those that we have mentioned above. For it is the king not the merchant who is paying for the erbum. So it is not plausible to think that the king should pay to the merchant tax for the goods the latter has brought to him. It can not be considered to mean present either as long as it is paid for. It seems quite obvious that the king's payment to the merchant is not due to his feeling of gratitude or kindness. Although he wants to pay 100 minas of Tuhpia copper for the kutänum-cloth Išme-Ašsur has brought to him, the merchant refuses to accept that sum hopping more. So the king is obliged to pay 50 minas of Tuhpia copper, 30 minas of good quality copper and additional 2 jars of oil.

Taking into consideration the contexts in which the word erbum has been used and what has been said about it, we may say that erbum is a collective name for the goods that have been ordered by the palace, and their price has to be paid.

L. 18: The word $z i-q \hat{u}-q \hat{a}^{!}-t i m$ which has not been found in Old Assyrian tablets until now is possibly the plural form of ziqqu "wine skin" (CAD ziqqu B).

\section{No.2}

Excavation inv. no. Kt. n/k 388.

The main theme of the letter written by $A h$-šalim addressing to four persons at the same time is probably the erbum taken to the king of Tamnia and the oath which the king says that he has received in Karahna. Ah-šalim is informing his colleagues of these topics. Also he tells them to send him a white dress and a piece of fine kutanum-cloth which the queen ordered..

Obv. 1. um-ma Ah-ša-lim-ma a-na

Šu-Ištar Ú-șur-ša-Ištar I-dí-ku-bi

$u^{d}$ En-líl-ba-ni qí-bi ${ }_{4}-\mathrm{ma}$

a-na ru-ba-im išs-tù sí-kà-tim 
5. i-tù-a-ri-š́u i-bá-tí-šu

am-hu-ur-šu-ma er-ba-am

a-ru-ba-im ú me-er-i-su Ta-am-ni-a-i-im

a-š́-i-ma um-ma šu-ut-ma

ma-mi-tám a-šu-mì-ku-nu-ma

10. a-Kà-ra-ah-na al-qí a-dí-i

KÙ. BABBARPí-ku-nu lá ha-lá-qí-im

i-ša-am-ší tup-pá-am

ú-lá-pí-ta-ku-nu-ni i-ša-nim

$u_{4}$-mì-im ma-mì-tám

Edge ša Kà-ra-ah-na

ú-bu-lu-[nim]-ma za- $\Gamma_{\text {ku-sà }}{ }^{\top}$

Rev. i-qá-bi-a-[ma] a-ša-pá-ra-ku-nu-tí

ki-ma tup-pí-i kà-ru-um

iš-me-ú kà-ra-am mu-ùh-ra-ma

20. té-er-ta-ấs-nu li-li-kam-ma

ma-lá KÙ.BABBAR ${ }^{p i}$-ku-nu

ša-lá-hi-im lc-pu-uś

a-wi-lúm a-na er-bi-im

i-da-gal 1 TÙG lu-bu-ša-am

25. pá-și-a-am ù TÚG ku-ta-nam

qá-at-num ru-ba-tum

té-ri-š́a-ni šé-bi ${ }_{4}-1 a ́-n i m$

šu-ma i-na Kà-ra-ah-na

gam-ra-am i-ga-mu-ru-ma

30. KÙ.BABBAR i-ŝ́a-lu-hu

té-er-ták-nu li-li-kam-ma 
Edge a-na-kam er-ba-am a-na

a-wi-lim pá-i a-dá-an

5 ma-na AN.NA

Left E. a-na ba-lu-sf-im É kà-ri-im er-ša-ma

Šé-bi ${ }_{4}$-lá-nim tê-er-ták-nu sú!-ha-ra-am

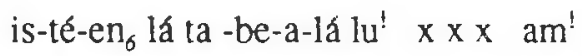

2 ra-dí-ú śa Lu'-ha-i-im iš́-tí-a wa-ấs-bu

\section{Translation:}

(1-3) “Thus (says) Ah-salim: 'Speak to Su-lšstar, Usur-ša-lštar, Id $\bar{l}-K \bar{u} b i(m)$ and Enlil-bäni: (4-8) I approached to the ruba' um in his region as he was returning from sikkatum, and I offered (brought) an erbum to the ruler of Tamnia and his son of Tamnia.' (8-11) He (the king) said thus: "The oath on bealf of you, I delivered at Karahna, in order that your silver does not get lost". (12-17) On the second day after you sent me the letter, they sent here (a copy) ${ }^{4}$ of the oath (taken in) Karahna and they will bring, and I will write you exactly what he says to me. (18-20) As soon as the kärum has read my tablet, tum to the kärum and let their instructions come to me. (21-22) I will salvage yours silver as well as I can. (23-24) The gentelman (the king) waits for an erbum. (24-27) The queen has ordered me a white dress and a picce of kutänum-cloth; send (it) to me. (28-31) Let your report come to me (to tell me) whether they have to make expenses in Karahna for salvaging the silver. (32-33) Here I am going to promise the gentelman an erbum. (34-36) You must ask of the office of $k \bar{a}$ rum 5 minas of tin for..... and send it to me. (36-37) As for (getting) your report (delivered), do not spare even one single servant (as messenger). (37-38)

Two guides from Luhajum are staying with me'.

\section{Notes:}

L.1-2: Among the four people whom Ah-salim addresses there is Usur-śa-Istar, who is known as a result of the studies on the tablets found at Kültepe (1962-Kt. $\mathrm{n} / \mathrm{k}$ ) to have had one of the biggest of the archives there.

The recent studies shows that a great part of the tablets found in $1958(\mathrm{Kt} . \mathrm{j} / \mathrm{k})$ and in $1962(\mathrm{Kt} . \mathrm{n} / \mathrm{k})$ belongs to the same archive. Among

4. The sentence, amma mehrat mamitim sa /ubllüniatini "Here is the copy they sent to us" (CCT IV 30 a 8-9) clarifies the question of (the copy of) oath being sent. 
these tablets there are many letters which Ah-Šalim had written to Usur-sa-Istar, his relations and friends. We leam from these letters that Ah-Salim had close relations with the palace and he brought various dresses and pieces of cloth to the king and the queen ${ }^{5}$.

L. 4-5: The meaning of the sentences such as istu sikkatim tuäru "to retum from sikkatum" and ilina tuwar sikkatim "on the return of sikkatum", which we find in several texts, depends on question what the word sikkatum means.

CAD under sikkatum B after referring to the meaning of the word as uncertain, goes on to suggest that in meaning it may have something to do with military expedition or army ${ }^{6}$.

It will not be irrelevant to quote here some of the passages in which sikkatum is used before we go on to determine its possible meaning in Old Assyrian language.

CAD gives under sikkatum B the following quotations:

ittuwär sikkatim weriam ana ša kima kunūti ušaśqalma .... tuwär sikkatim qurub "On the return of sikkatum, I will pay the copper to your representatives and... the retum of the sikkatum is immient" (Also this letter in TC 2, 37 has been written by Ah-Salim).

adi 2 [ümi] sikkatum iturränim atabbiamma atalkam "the sikkatums will return in two days, immediately depart and come here."

warkišunuma sikkatum [ü/si u mahirum parrudma "After their departure the sikkatums went out and bussiness was unsettled."

5. The quen is said in the letter (L.24-27) to have ordred a white dress and pieces of fine kutanum-cloth for herself. There are some examples of similar expressions in Ah-Šlim's other letters:

$\mathrm{Kt} . \mathrm{n} / \mathrm{k} 211,24-26:$ He is reportig that the queen has requested for pieces of fine kutänum-cloth.

Kt. $\mathrm{n} / \mathrm{k} 419,20-21$ (a letter he sends to Ușur-ša-lštar): lubüšam pașium šébilam "Send the white dress".

Kt. n/k 533, 16-22: Jumma TÚG.HI.A lu lubüšam paşium lu abarnium

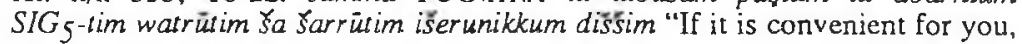
give her (L. 11: awiltum probably the queen) the piece of cloth for the white dress and the very high quality abarnium-cloth or royal quality.

Kt. j/k 197, 22-24 (a letter he sends to Uzubiskim): annakam É.GAL-lúm ana subati ušamtuni "Here the palace has wamed me of the pieces of my cloth.

Kt. j/k 121, 18-21 (a letter to Usur-ša-Istar and Uzubiškim): išteniš 10 TÚG śa Akkidie 30 TUG kutāni $S_{1} G_{5}$ ša kuburri rubä'im šebilänim "send here the 10 pieces of Akkadian cloth together with 30 pieces of thick, good quality kutanum-cloth for the king.

6. Cf, K.R. Veenhof, AOATT, p.330, n.445; “T. Ozgulç'e Armağan” (1989), p.521-522. 
ana sikkatim allak kuāum mêr'aka anāku ina šêpija allak..... ana sikkatim larkabma "I am going to go to the sikkatum, I am your own son, shall I go on foot? Let me ride to the sikkatum."

2 raqqitèn ana sikkatim arrubä' im $u$ PN $i d d i n u ̈$ "They gave two fine textilles to the ruba' um and to PN for the sikkatum."

ina šamši rubä' um Wa-âš-ha-na-i-um ina sikkatim ituranni "On the day when ruler of Wašhania returned from the sikkatum."

Examples from the unpublished texts:

Kt. n/k 128, 5: sikkatum ruqāma "sikkatum is far away"

Kt. v/k 57, 12-21: mimma ana sikkatim tūsāni latbima lattallakma ....ümam išsti Salatuar ana sikkatim nitişi.... ina tuär sikkatim awili anahhidma "When you depart for the sikkatum. let me (also) go (there) ...Today we left Šalatuar for sikkatum.... On return from sikkatum, I shall take care of the men."

Kt. n/k 16897, 5-16: sikkätum usāma ina mahīrim KÜ.BABBAR ù KÙ.GI lašs̆u... sikkatum ana 10 ümi iturrānnimma KÙ.GI aša'amma "The sikkatum have gone by and there is not silver and gold in the market.... sikkàtum will return about in ten days' time and I will buy gold."

Taking these examples into consideration, I am inclined to thinks that the word sikkatum is used to mean a kind of 'fair' which takes place in a certain time and ground and during which mainly various metals, apart from other things, are sold and bought. rabi sikkätim/sikkitim were the leaders of the sikkattum officers who were responsible for the organization and administration of it. The quotations from the related texts above and the context in which sikkatum is used show that the shortage or abundance of metals in the market and the success of the market in buying and selling are closely related to the question whether they (sikkâtum) come to the fair or not.

L.9-16: The firs thing in the letter that captures our attention is that rubä' um is said to have received an oath of loyalty in Karahna a center of wabartum.

The texts KTP 14 and Kt. $\mathrm{f} / \mathrm{k} 183$ are still the most important sources $^{8}$ to refer to in the matter of oath. They prove that the kings on

7. S. Çeçen, Doctorate Thesis, text no.50.

8. KTP 14, B has been published by B. Landsberger (TTAED 4, p.26 ff.); Kt. f/K 183 by K. Balkan (Kronoloji, p.36-38). Both texts have been fully discussed by L.L. Orlin (ACC p.114-123). 
their accession to the thrones in Anatolia generally received from the Assyrian merchants or their representatives a kind of loyalty the details of which we do not know for certain.

L. 34-35: AN-NA a-na ba-lu-si-im: I do not know how to explain this expression.

L. 38: Lu-ha-i-im: Luhã, the name of a place, does not occur in the form of nisbe in the texts. Some scholars take Luhä= Eluhut, the nisbe of which has not been found yet ${ }^{9}$.

$\mathrm{CCT}, 44^{c}$ is an important source to localize Luhā. According to this text Luhă seems to be third station from Abum (Tel Leylan).

9. See K.R. Veenhof, AOATT, p.242, n.375; cf. K. Nashef, RGTC IV, p.38-39. 
No.1 (Kז.85/א.27)

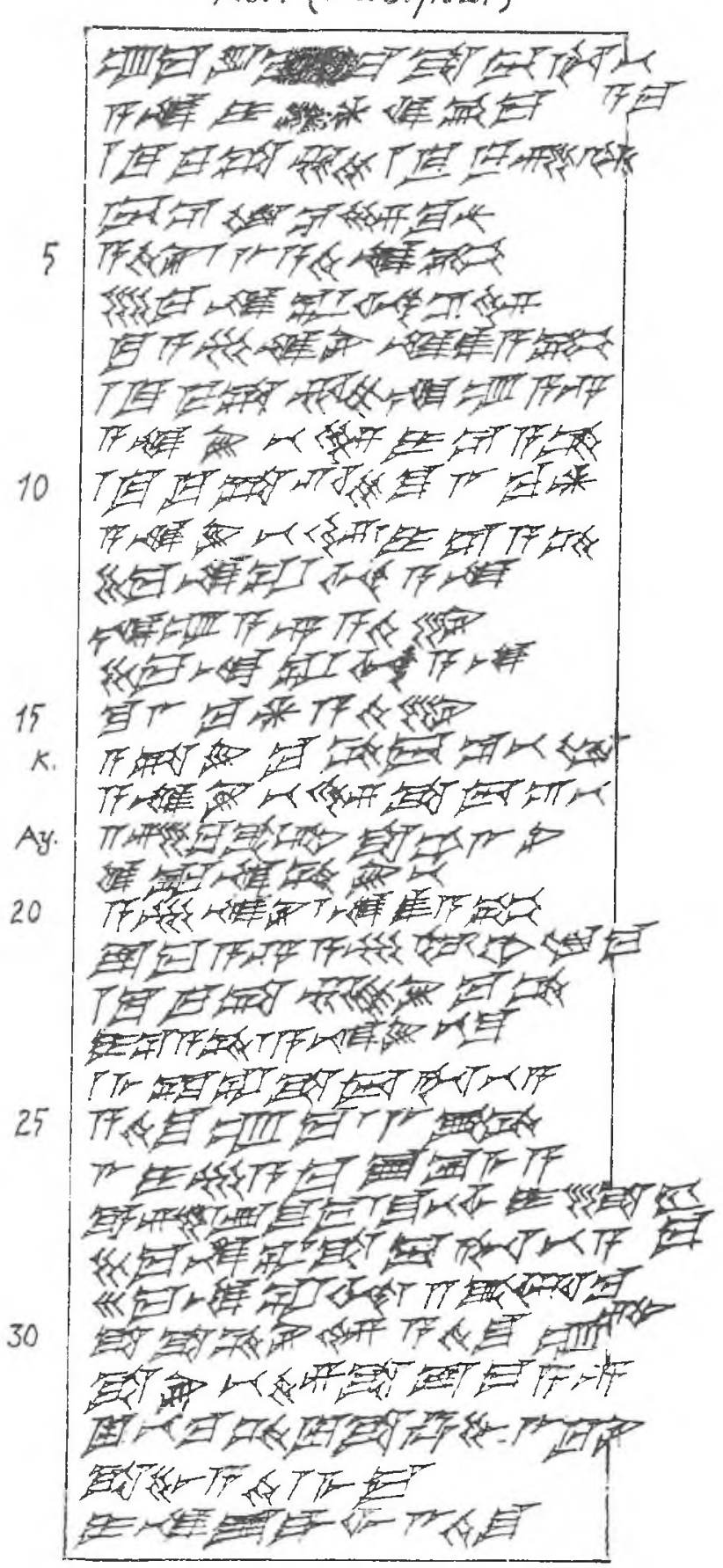


No.2(Kz.n/k388)

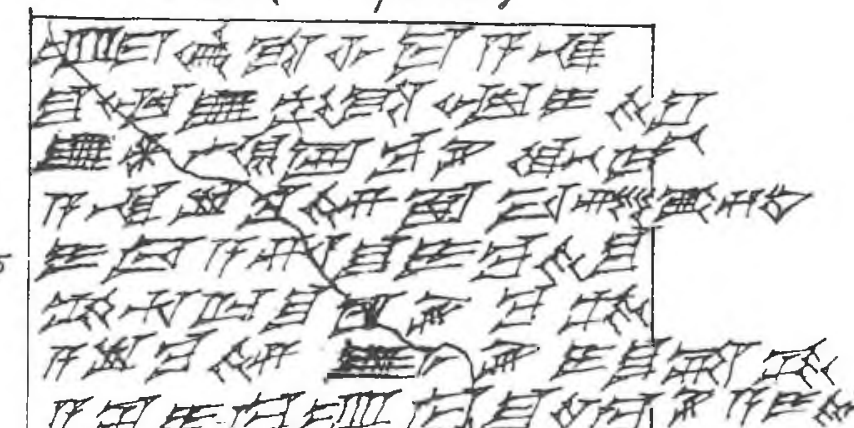

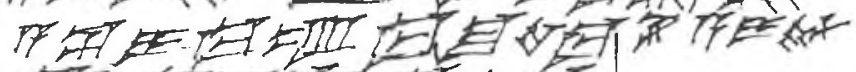

过

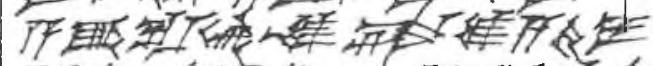

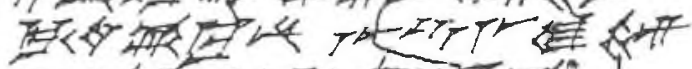

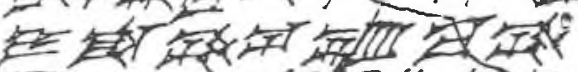

蛙

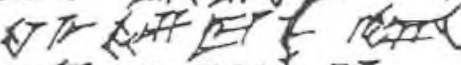

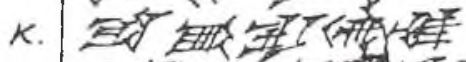

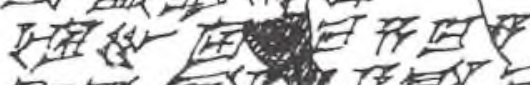

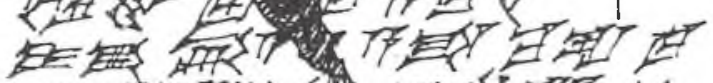

FA

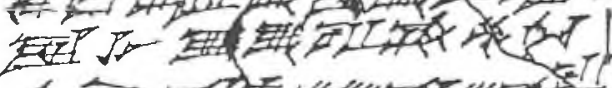

स 两

E

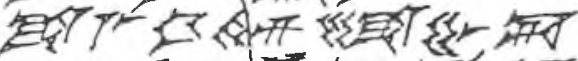

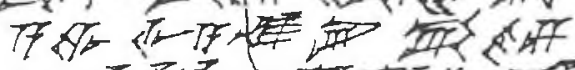

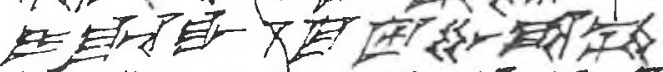

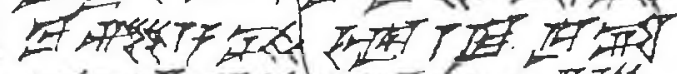

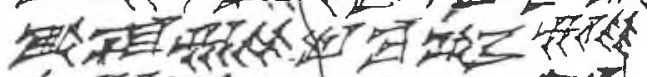

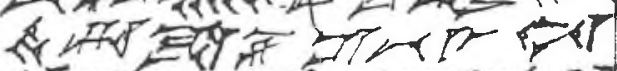

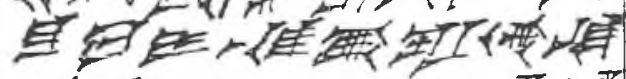

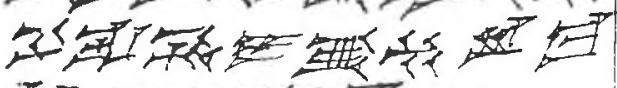

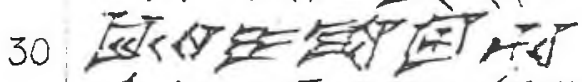

伤开

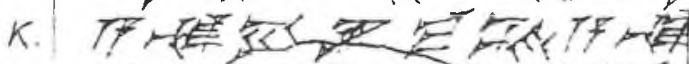

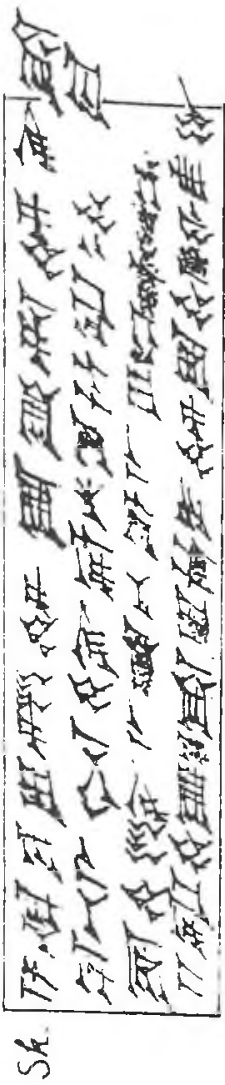

7 ST

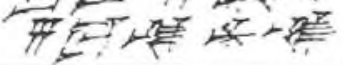

